cPherson, A. 1952. Burrowing Owls. Blue Jay $10: 3$.

acoun, John, and James M. 1909. Catalogue of Canadian birds. Government Printing Bureau, Ottawa.

itchell, Hedley H. 1924. Birds of Saskatchewan. Canadian Field-Naturalist 38:101-118. aine, Walter. 1892. Bird-nesting in NorthWest Canada. Hunter, Rose \& Co., Toronto. anty, Dave. 1962. Apparent breeding record of Turkey Vulture along South Saskatchewan River. Blue Jay $20: 14$.

ymons, R. D. 1967. Hours and the birds. University of Toronto Press, Toronto.

\section{BROWN THRASHER AT ISLAND LAKE, MANITOBA}

by A. E. Wilson, Island Lake

A Brown Thrasher found by 12ear-old Norman Wood is a new pecies record for Island Lake, Maniba. The bird was found almost dead rom cold under a boat on November 1, 1968. The bird undoubtedly was straggler and not a local resident, $r$ its breeding range lies far to the outh. Godfrey (1966. The birds of anada) gives Dauphin as a northern reeding locality in Manitoba. Incientally, this is a species unfamiliar the boy's father who is a life-long sident of Island Lake.

R. W. Nero informs me that J. R. ehl, Jr. and Mrs. I Smith list the rown Thrasher in their coming reised account of the birds of Churchill icinity, far to the north of Island ake. Its occurrence at both places lust be regarded as accidental.

The date of its occurrence is late $r$ this species in any case. Bent 1948. Life histories of North Amerian nuthatches, wrens, thrashers and heir allies) mentions dates in Sepember and early October as late eparture dates for Canadian localies; November 13 is the latest date iven for Washington, D.C. The pecimen will be given to the Maniba Museum of Man \& Nature in Vinnipeg.

Editor's Note: Because la'te fall eparture dates are unusual for the rown Thrasher, it is worth menoning here that $\mathrm{Al}$ and Betty Binnie ecorded a Brown Trasher seen at legina as late as December. 21, 1968.]

\section{OWL AND HAWK NESTS}

Anyone finding an active nest of any bird of prey in Saskatchewan, is asked to contact Dr. Stuart Houston, 863 University Drive, Saskatoon, who will notify the nearest bander. Nests within 50 miles of Saskatoon, Regina, Indian Head or Yorkton will be visited and the young banded; nests at a greater distance may be visited, including most of those within 100 miles of Saskatoon, depending on numbers, and time available. With the declining numbers of many birds of prey, including now the Marsh Hawk, it is important to learn all we can of nesting success and migration routes. Experience has shown that banding visits do not adversely affect nesting success, but have contributed greatly to our knowledge.

\section{PRAIRIE NEST RECORDS SCHEME}

Contributors are reminded to send 1969 nest record cards to Dr. Robert W. Nero, Prairie Nest Records Scheme, Manitoba Museum of Man and Nature, Winnipeg 2. If you have not previously contributed to the scheme but are interested in keeping records, write to $\mathrm{Dr}$. Nero for information and nest record cards. Also available from him is the summary of the scheme's first 10 years operation (1958-67).

\section{GREAT GRAY OWL CONCENTRATION}

Great Gray Owls appeared unexpectedly in southeastern Manitoba in late October and early November, 1968. They have since been seen in a number of localities in an area of about 45 miles by 75 miles extent bordering the west side of the Whiteshell Provincial Park east of Winnipeg. Largest numbers have been seen near extensive stands of lowland black spruce, but they have been sighted in a variety of habitats and 